\title{
PENGARUH VARIASI BERAT ARANG SEKAM PADI SEBAGAI MEDIA ADSORBEN DALAM MENURUNKAN KADAR BESI (FE) PADA AIR DI BANYUMAS
}

\author{
Syarifatul Nur Ai'ni ${ }^{1)}$, Budi Triyantoro' ${ }^{1)}$, Sugeng Abdullah ${ }^{1)}$ \\ Poltekkes Kemenkes Semarang
}

\begin{abstract}
Abstrak
Aktivitas manusia dalam memenuhi kebutuhan hidup pasti menghasilkan dampak terhadap lingkungannya. Salah satunya aktivitas di industri yang menghasilkan limbah. Air limbah industri yang mengandung logam berat merupakan toksikan yang mempunyai daya racun yang tinggi. Menurut Sugiarto (1987) air limbah yang mengandung besi $(\mathrm{Fe})$ berasal dari kegiatan industri, terutama pada industri penyepuhan logam. Kadar besi dalam air dapat diturunkan dengan menggunakan karbon aktif sebagai media adsorben.Karbon aktif dapat diperoleh dari arang, salah satunya arang sekam padi. Tujuan penelitian adalah untuk membuat mengetahui pengaruh variasi berat arang sekam padi untuk menurunkan kadar besi $(\mathrm{Fe})$ pada air.

Jenis penelitian ini adalah pra eksperimen dengan metode pre and post design. Variabel yang diteliti yaitu kadar besi $(\mathrm{Fe})$. Terdapat 3 replikasi dan 3 perlakuan. Jumlah sampel yang digunakan sebanyak 9 sampel. Uji statistic yang digunakan yaitu Kruskal Wallis.

Hasil penelitian menunjukkan bahwa variasi berat arang sekam padi tidak berpengaruh dengan penurunan kadar besi $(\mathrm{Fe})$ pada air, dengan hasil siginifikan 0,109. Tetapivariasiberatarangsekam padi yang paling berpengaruh yaitu variasi berat $2 \mathrm{~kg}$ dengan signifikan 0,05 .

Simpulan dari hasil penelitian bahwa secara statistik tidak ada perbedaan bermakna pada penggunaan arang sekam padi dalam menurunkan kadar besi (Fe) pada air. Disarakan sebaiknya perlu memperhatikan kembali kualitas arang sekam padi yang digunakan, serta bahan untuk pembuatan besi (Fe).
\end{abstract}

Kata Kunci : Arang Sekam Padi, Besi (Fe)

\section{Abstract}

Human activity in fulfilling file needs cause an impact on the environment. One of it is the eactivities in the industry that produce waste. Industrial wastewater containing heavy metals which is a toxicant has a high toxicity. According to Sugiarto (1987) wastewater containing iron (Fe) comes from industrial activities. Especially in the metal plating industry. Iron content in water can be reduced by using activated carbon as an adsorbent. Activeted carbon can be obtained from charcoal, one of it was obtained from rice husk charcoal to reduce levels of iron $(\mathrm{Fe})$ in water.

This type of research is Pre-Experimental with pre and post design methods. The variables studied were iron $(\mathrm{Fe})$ levels. There are 3 replications and 3 treatments. The number of samples used were 9 sampels. The test statistic used was Kruskal Wallis.

The results showed that weight variations of rice husk charcoal had no effect with decreasing levels of iron (Fe) in water, with a significant result 0,109. But the most influental variation in the weight of rice husk charcoal is the weight variation $2 \mathrm{~kg}$ with the significant 0.05 .

Conclusion from the results of the study that there was no statistically significant difference in using rice husk cahrcoal. For reducing level of iron $(\mathrm{Fe})$ in water and suggested for pay attention to the qualty of the rice husk charcoal used, as well as the materials for making iron $(\mathrm{Fe})$

Keyword: Rice Husk Charcoal, Iron (Fe) 


\section{PENDAHULUAN}

Aktivitas manusia dalam memenuhi kebutuhan hidup pasti menghasilkan dampak terhadap lingkungan. Dampak tersebut dapat berupa dampak positif maupun negatif,baik bagi alam lingkungan maupun bagi manusia dan mahkluk hidup yang lain. Salah satu dampak negatif akibat aktivitas manusia, yaitu turunnya kualitas lingkungan hidup. Turunnya kualitas lingkungan yang diakibatkan oleh pencemaran air limbah yang dihasilkan oleh aktifitas manusia, baik dari air limbah rumah tangga, in-dustri, maupun pertanian.Air limbah industri yang mengandung unsur atau senyawa logam berat merupakan toksikan yang mempunyai da-ya racun yang tinggi. Kandungan logam berat pada air limbah dapat mencemari lingkungan alam.

Alam memiliki kemampuan dalam menetralisir pencemaran yang terjadi apabila jumlahnya kecil, akan tetapi apabila dalam jumlah yang cukup besar akan menimbulkan dampak negatif terhadap alam, karena dapat mengakibatkan terjadinya perubahan keseimbangan lingkungan, sehingga air limbah tersebut dikatakan telah mencemari lingkungan. Hal ini da-pat dicegah dengan mengolah air limbah yang dihasilkan industri, sebelum dibuang ke badan air. Air limbah yang dibuang ke badan air ha-rus memenuhi baku mutu yang telah ditetap-kan, karena badan air merupakan salah satu sumber air bersih bagi masyarakat, sehingga badan air tersebutdapat digunakan untuk berbagai keperluan sehari-hari.

Menurut Sugiharto (1987), air limbah yang Fe dapat berasal dari kegiatan industri, te-rutama pada industri penyepuhan logam. Pada penelitian yang telah dilakukan oleh M. Arif (2012), sampel tanah dari lahan sawah di sekitar industri penyepuhan logam di Keca-matan Juawana, Kabupaten Pati yang tidak dilakukan pengolahan air limbah, sehingga kandungan besi $(\mathrm{Fe})$ dan, alumunium (Al) di dalam tanah sawah tergolong tinggi. Masing-masing berkisar antara 28,282 $61,210 \mathrm{ppm}$ dan 42,984 - 121,070 ppm, dengan demikian kadar tersebut tidak sesuai dengan baku mutu air limbah yang ada, sehingga dapat menye-babkan berbagai gangguan, salah satunya gangguan kesehatan yang berupa penyakit pada manusia.

Menurut (Jasman, 2011), penyakit yang disebabkan oleh $\mathrm{Fe}$ adalah anemia atau kekurangan sel darah merah. Penyakit anemia terjadi karena konsumsi zat besi pada tubuh tidak seimbang atau kurang dari kebutuhan tubuh. Zat besi merupakan mikro elemen yang esensial bagi tubuh, yang sangat diperlukan dalam pembentukan darah, yakni dalam hemo-globin $(\mathrm{Hb})$. Kadar besi yang berlebihan dalam tubuh manusia dapat merusak dinding usus dan sering mengakibatkan kematian. Berdasarkan Peraturan
Daerah Jawa Tengah No. 5 Tahun 2012, tentang Baku Mutu Air Limbah kadar besi dalam air limbah maksimum diperboleh-kan 5,0 mg/l, sedangkan menurut Peraturan Pemerintah RI No. 82 Tahun 2001, tentang Pengelolaan Kualitas Air dan Pengendalian Pencemaran Air kandungan Fe yang diizinkan adalah sebesar $0,3 \mathrm{mg} / \mathrm{l}$.

Margono (2010), bahwa kadar besi dalam air dapat diturunkan dengan mengguna-kan karbon aktif sebagai media saring. Karbon aktif adalah sejenis absoren (penyerap), ber-warna hitam, berbentuk granula, bulat, pelet atau bubuk. Arang dapat digunakan untuk meng-hilangkan bau dan warna pada air. Arang merupakan suatu padatan berpori yang meng-andung 85-95\% Karbon, dihasilkan dari bahan-bahan yang mengandung Karbon dengan pe-manasan pada suhu tinggi.

Arang merupakan suatu padatan berpori yang mengandung $85-95 \%$ Karbon, dihasilkan dari bahan-bahan yang mengandung Karbon dengan pemanasan pada suhu tinggi. Ketika pemanasan berlangsung, diusahakan tidak terjadi kebocoran udara di dalam ruangan pemanasan, sehingga bahan yang mengandung Karbon tersebut hanya mengalami karbonisasi dan tidak teroksidasi, selain digunakan sebagai bahan bakar, arang juga dapat digunakan sebagai adsorben (penyerap). Arang dapat berasal dari sekam padi, karena pada sekam padi mengandung beberapa unsur kimia yang baik untuk dijadikan arang yang berasal dari sekam padi.Salah satu bahan yang dapat dimanfaatkan untuk membuat arang aktifyaitu sekam padi.

Menurut Jasman (2013), sekam padi mengandung beberapa unsur kimia, yaitu : kadar air $(9,02 \%)$, protein kasar $(3,03 \%)$, lemak $(1,18 \%)$, serat kasar $(35,68 \%)$, Abu $(17,17 \%)$, Karbohidrat (33,71\%), Karbon (zat arang) $1,33 \%$, Hidrogen $1,54 \%$, Oksigen $33,64 \%$, dan Silika $16,98 \%$. Arang sekam padi bersifat porous, ringan, tidak kotor dan cukup dapat menahan air. Daya serap ditentukan oleh luas permukaan partikel. Kemampuan arang sekam padi dapat menjadi lebih tinggi jika dilakukan aktivasi terhadap arang sekam padi tersebut dengan bahan-bahan kimia atau dengan pemanasan pada temperatur tinggi. Dengan demikian, arang sekam padi akan mengalami perubahan sifat-sifat fisika dan kimia. Arang sekam padi tersebut disebut sebagai arang aktif. Menurut Margono (2010) karbon aktif dapat dipergunakan dengan cara dicampur di dalam air limbah, kemudian dijadikan sebagai adsorben dan sebagainya. Arang aktif yang berasal dari arang sekam padi sangat efektif untuk menghilangkan warna, bau dan rasa dalam air.

Tujuan penelitian ini adalah mengetahui efektivitas variasi beratpenggunaanarang se-kam padi sebagai media adsorben dalam me-nurunkan kadar besi (Fe) pada air. 
II. Bahan dan Metode

Jenis penelitian yang digunakan adalah Quacy Experimental dengan metode Non equvalent group control Pretest-Posttes Design dengan maksud untuk mengetahui ada atau tidak adanya perbedaan kadar besi (Fe) se-belum dilakukan penyaringan dengan arang sekam padi dan sesudah dilakukan penyaringan dengan arang sekam padi. Populasi dari penelitian ini adalah air limbah industri di kabupaten Banyumas, dan jumlah sampel sebanyak 10 sampel.

Variabel bebas dalam penelitian ini adalah variasi berat arang sekam padi. Variabel terikat dalam penelitian ini adalah kadar besi $(\mathrm{Fe})$ awal pada air.Variabel pengganggu dalam penelitian ini adalah $\mathrm{pH}$, suhu, bau, rasa, kekeruhan. Variabel kontrol dalam penelitian ini adalah lama pengadukan, volume air, filter, pendiaman.

Instrument pada penelitian ini yaitu menggunakan: Spektofotometer untuk mengukur kadar besi (Fe), gelas ukur dan tabung erlenmeyer untuk mengukur volume air, stopwach untuk mengukur waktu karbonisasi, waktu kontak dan waktu aktivasi, pH meter untuk mengukur $\mathrm{pH}$ air, thermometer alkohol untuk mengukur suhu air, panca indra manusia untuk pemeriksaan organoleptik bau dan rasa. Hasil dianalisis menggunakan program aplikasi statistik, data yang dianalisis yaitu analisis univariate, analisis bivariate menggunakan uji wilcoxon, dan analisis multivariate menggunakan kruskal wallis.

\section{Hasil dan Pembahasan}

Univariate

a. Suhu

Tabel 3.1 : Hasil Pengukuran Suhu

\begin{tabular}{llcc}
\hline No. & \multicolumn{1}{c}{$\begin{array}{c}\text { Unit } \\
\text { Percobaan }\end{array}$} & $\begin{array}{c}\text { Sebelum } \\
\text { Perlakuan }\end{array}$ & $\begin{array}{c}\text { Sesudah } \\
\text { Perlakuan }\end{array}$ \\
\cline { 3 - 4 } 1. & Sampel 1.1 & 26 & 26 \\
2. & Sampel 1.2 & 26 & 27 \\
3. & Sampel 1.3 & 26 & 27 \\
4. & Sampel 2.1 & 26 & 26 \\
5. & Sampel 2.2 & 26 & 27 \\
6. & Sampel 2.3 & 26 & 26 \\
7. & Sampel 3.1 & 26 & 27 \\
8. & Sampel 3.2 & 26 & 28 \\
9. & Sampel 3.3 & 26 & 28 \\
\hline \multicolumn{5}{c}{ Minimal } & 26 & 26 \\
\hline & Maksimal & 26 & 26,8 \\
\hline & Rata-rata & 26 & 26 \\
\hline
\end{tabular}

\section{Keterangan :}

Sampel $1.1=$ Replikasi 1 arang sekam pagi 1 $\mathrm{kg} / 14$ liter

Sampel $1.2=$ Replikasi 1 arang sekam pagi 1 $\mathrm{kg} / 14$ liter

Sampel $1.3=$ Replikasi 1 arang sekam pagi 1 $\mathrm{kg} / 14$ liter
Sampel $2.1=$ Replikasi 2 arang sekam pagi 2 $\mathrm{kg} / 14$ liter

Sampel $2.2=$ Replikasi 2 arang sekam pagi 2 $\mathrm{kg} / 14$ liter

Sampel $2.3=$ Replikasi 2 arang sekam pagi 2 $\mathrm{kg} / 14$ liter

Sampel $3.1=$ Replikasi 3 arang sekam pagi 3 $\mathrm{kg} / 14$ liter

Sampel $3.2=$ Replikasi 4 arang sekam pagi 3 $\mathrm{kg} / 14$ liter

Sampel $3.3=$ Replikasi 3 arang sekam pagi 3 $\mathrm{kg} / 14$ liter

Pengukuran suhu pada air yang mengandung besi $(\mathrm{Fe})$ dilakukan sebelum perlakuan dan sesudah perlakuan dengan menggunakan arang sekam padi, yang pengukuran suhunya menggunakan thermometer air. Data hasil pengukuran suhu air yang mengandung besi $(\mathrm{Fe})$ sebelum perlakuan dan sesudah perlakuan dapat dilihat pada tabel 3.1. Berdasarkan pengukuran tersebut didapatkan rata-rata suhu sebelum perlakuan : $26^{\circ} \mathrm{C}$ dan sesudah per-lakuan : 26,8 ${ }^{\circ} \mathrm{C}$. Temperatur yang dikeluarkan suatu limbah cair harus merupakan temperatur alami. Suhu air limbah akan seimbang jika selisih dengan suhu udara luar sebesar $\pm 3{ }^{\circ} \mathrm{C}$. Selama percobaan suhu udara $26{ }^{\circ} \mathrm{C}$. Ber-dasarkan hal tersebut selisih suhu udara dengan suhu air limbah adalah $\pm 2{ }^{\circ} \mathrm{C}$, yang berarti sudah seimbang (Permenkes No. 32 Tahun 2017).

Temperatur pada air juga mendukung tingginya kelarutan besi (Fe) dalam air. Temperatur yang rendah menyebabkan kenai-kan kadar oksigen terlarut (DO) dalam air. Penurunan temperatur air menyebabkan air tidak dapat menguraikan derajat kelarutan mi-neral, sehingga kelarutan besi $(\mathrm{Fe})$ pada air tinggi. Kelarutan logam berat juga dipengaruhi oleh kondisi DO di perairan (Endang dan Hadi, 2015). Dengan demikian dapat diasumsikan semakin rendah suhu pada air, maka semakin baik pengaruh penurunan kadar besi $(\mathrm{Fe})$ pada air. Akan tetapi pada kenyataan penelitian, suhu sudah memenuhi persayaratan, tetapi tidak berpengaruh terhadap penurunan kadar besi $(\mathrm{Fe})$.

b. $\mathrm{pH}$

Tabel 3.2 : Hasil Pengukuran pH

\begin{tabular}{|c|c|c|c|}
\hline \multirow[b]{2}{*}{ No. } & \multirow{2}{*}{$\begin{array}{c}\text { Unit } \\
\text { Percobaan }\end{array}$} & \multicolumn{2}{|c|}{$\mathrm{pH}$} \\
\hline & & $\begin{array}{c}\text { Sebelum } \\
\text { Perlakuan }\end{array}$ & $\begin{array}{c}\text { Sesudah } \\
\text { Perlakuan }\end{array}$ \\
\hline 1. & Sampel 1.1 & 3,7 & 3,3 \\
\hline 2. & Sampel 1.2 & 3,7 & 2,9 \\
\hline 3. & Sampel 1.3 & 3,7 & 3,1 \\
\hline 4. & Sampel 2.1 & 3,7 & 2,8 \\
\hline 5. & Sampel 2.2 & 3,7 & 2,9 \\
\hline 6. & Sampel 2.3 & 3,7 & 3,0 \\
\hline 7. & Sampel 3.1 & 3,7 & 4,0 \\
\hline 8. & Sampel 3.2 & 3,7 & 3,7 \\
\hline 9. & Sampel 3.3 & 3,7 & 3,5 \\
\hline & Minimal & 3,7 & 2,9 \\
\hline & Maksimal & 3,7 & 4,0 \\
\hline & Rata-rata & 3,7 & 3,2 \\
\hline & $\begin{array}{l}\text { pH tanpa } \\
\text { perlakuan }\end{array}$ & \multicolumn{2}{|c|}{3,7} \\
\hline
\end{tabular}


Pengukuran $\mathrm{pH}$ pada air yang mengan-dung besi (Fe) dilakukan sebelum perlakuan dan sesudah perlakuan dengan menggunakan arang sekam padi, yang pengukuran menggu-nakan $\mathrm{pH}$ meter. Data hasil pengukuran $\mathrm{pH}$ air yang mengandung besi $(\mathrm{Fe})$ sebelum perlakuan dan sesudah perlakuan dengan arang sekam padi dapat dilihat pada tabel 3.2. Berdasarkan hasil pengukuran yang telah dilakukan dida-patkan hasil $\mathrm{pH}$ rata-rata sebelum perlakuan :3,7 dan sesudah perlakuan : 3,2 .

Hasil dari pengukuran $\mathrm{pH}$ selama pene-litian cenderung rendah (asam) yaitu antara 2,9 - 4,0. $\mathrm{pH}$ air berpengaruh terhadap kesadahan kadar besi dalam air, apabila $\mathrm{pH}$ air rendah akan berakibat terjadinya proses korosif se-hingga menyebabkan larutnya besi $(\mathrm{Fe})$ dan logam lain dalam air. Menurut Begum et al 2009 (Soedharto, 2013) pH $<7$ dapat me-laruttkan logam. Pada keadaan $\mathrm{pH}$ rendah besi $(\mathrm{Fe})$ yang berada dalam air berbentuk Ferro $\left(\mathrm{Fe}^{2+}\right)$ dan Ferri $\left(\mathrm{Fe}^{3+}\right)$, dimana bentuk Ferri akan mengendap dan tidak larut dalam air sertaFerro tidak dapat dilihat dilihat, sehingga mengakibatkan air menjadi berwarna, berbau dan berasa.

Terdapat beberapa faktor yang menyebabkan penurunan $\mathrm{pH}$ sehingga $\mathrm{pH}$ menjadi lebih asam atau rendah, yaitu terurainya bahan pembuat kadar besi $(\mathrm{Fe})$ pada air yang digunakan dalam penelitian, yaitu $\mathrm{FeCl} 2$ yang terurai menjadi :

$$
\mathrm{FeCl}_{2}+\mathrm{H}_{2} \mathrm{O} \longrightarrow \mathrm{Fe}^{2+} \mathrm{O}+2 \mathrm{HCl}
$$

Berasal dari reaksi $\mathrm{FeCl} 2$ terurai membentuk $\mathrm{Fe}^{2+} \mathrm{O}$ dan $2 \mathrm{HCl}$ maka $2 \mathrm{HCl}$ tersebut yang menyebabkan $\mathrm{pH}$ pada sampel menurun. Hidrogen klorida (HCL) adalah asam monoprotik, yang berarti bahwa HCL dapat terdisosiasi (teronisasi) melepas satu $\mathrm{H}^{+}$(sebuah proton tunggal) hanya sekali, dalam larutan asam klorida $\mathrm{H}^{+}$tersebut bergabung dengan molekul air membentuk ion hidronium, $\mathrm{H}_{3} \mathrm{O}^{+}$

$$
\mathrm{HCl}+\mathrm{H}_{2} \leadsto \longrightarrow \mathrm{H}_{3} \mathrm{O}^{+}-\mathrm{Cl}^{-}
$$

Ion lain yang terbentuk adalah ion klorida $\left(\mathrm{Cl}^{-}\right)$, asam klorida merupakan asam kuat karena dapat terdiosiasi penuh dalam air.

Kelarutan berbagai jenis logam sangat ditentukan oleh $\mathrm{pH}$ larutan, kecuali logam perak, pola umum kelarutan logam menurun dengan meningkatkan $\mathrm{pH}$ larutan dan setelah mencapai tingkat kelarutan minimum kemudian meningkat lagi dengan meningkatnya $\mathrm{pH}$ (Suprihatin dan Nastiti, 2010). Nilai pH memiliki hubung-an erat dengan sifat kelarutan logam berat. Lo-gam berat sukar terurai dan dalam bentuk partikel atau padatan tersuspensi. Pada $\mathrm{pH}$ rendah ion bebas logam berat dilepaskan di air, selain itu $\mathrm{pH}$ juga dapat mempengaruhi toksistas suatu suatu senyawa kimia. Secara umum $\mathrm{pH}$ logam berat akan meningkatkan toksisitasnya pada $\mathrm{pH}$ rendah (Arief Hapyy, dkk., 2012) c. Pengukuran Organoleptik Rasa

Tabel 3.3 : Pengukuran Organoleptik

\begin{tabular}{|c|c|c|c|c|c|}
\hline \multirow{3}{*}{ No. } & \multirow{3}{*}{$\begin{array}{c}\text { Unit } \\
\text { Percobaan }\end{array}$} & \multicolumn{4}{|c|}{ Rasa } \\
\hline & & \multicolumn{2}{|c|}{ Sebelum } & \multicolumn{2}{|c|}{ Sesudah } \\
\hline & & Berasa $\begin{array}{l}\mathrm{T} \\
\mathrm{b}\end{array}$ & $\begin{array}{l}\text { Tidak } \\
\text { serasa }\end{array}$ & Berasa & $\begin{array}{l}\text { Tidak } \\
\text { berasa } \\
\end{array}$ \\
\hline 1. & Sampel 1.1 & - & $\checkmark$ & - & $\checkmark$ \\
\hline 2. & Sampel 1.2 & - & $\checkmark$ & - & $\checkmark$ \\
\hline 3. & Sampel 1.3 & - & $\checkmark$ & - & $\checkmark$ \\
\hline 4. & Sampel 2.1 & - & $\checkmark$ & - & $\checkmark$ \\
\hline 5. & Sampel 2.2 & - & $\checkmark$ & - & $\checkmark$ \\
\hline 6. & Sampel 2.3 & - & $\checkmark$ & - & $\checkmark$ \\
\hline 7. & Sampel 3.1 & - & $\checkmark$ & - & $\checkmark$ \\
\hline 8. & Sampel 3.2 & - & $\checkmark$ & - & $\checkmark$ \\
\hline 9. & Sampel 3.3 & - & $\checkmark$ & - & $\checkmark$ \\
\hline & $\begin{array}{l}\text { Rasa tanpa } \\
\text { perlakuan }\end{array}$ & - & $\checkmark$ & - & $\checkmark$ \\
\hline
\end{tabular}
Rasa

Pengukuran organoleptik rasa pada air yang mengandung besi $(\mathrm{Fe})$ dilakukan sebelum perlakuan dan sesudah perlakuan dengan menggunakan arang sekam padi. Pengukuran organoleptik rasa menggunakan 5 orang pane-lis, yang masing-masing panelis mencicipi rasa air yang mengandung besi $(\mathrm{Fe})$ tersebut. Data hasil pengukuran organoleptik rasa pada air yang mengandung besi $(\mathrm{Fe})$ sebelum dan sesudah perlakuan dapat dilihat pada tabel 3.3. Berdasarkan hasil pemeriksaan tersebut sampel air yang mengandung besi $(\mathrm{Fe})$ tidak memiliki rasa atau tidak berasa baik setelah perlakuan maupun sesudah perlakuan. Hal tersebut juga terjadi pada sampel air yang mengandung besi $(\mathrm{Fe})$ yang tanpa perlakuan, sampel tersebut tidak memiliki rasa atau tidak berasa.

Hasil pemeriksaan organoleptik rasa selama penelitian air yang mengandung besi $(\mathrm{Fe})$ tersebut tidak memiliki rasa atau tidak berasa. Ada beberapa bahan polutan yang memberikan efek rasa pada air, seperti ; besi dan mangan yang memberikan rasa seperti logam, sodium, chloride, dan sulfat yang memberikan rasa sedikit asin, serta dapat pula disebabkan oleh adanya mikroba dalam air (Nelson, 1992 dalam Tata Afifani dan Ririh 2013). Pada peneletian ini air yang mengan-dung besi $(\mathrm{Fe})$ tidak memiliki rasa atau tidak berasa kemungkinan dapat disebabkan oleh tidak adanya mikroba dalam air, dikarenakan air yang dimengandung besi tersebut berasal dari air yang sudah memenuhi syarat (aquades) yang ditambahkan $\mathrm{FeCl}_{2}$ sebagai bahan untuk membuat air tersebut menjadi air yang meng-andung besi $(\mathrm{Fe})$. 
d. Organoleptik Bau

Tabel 3.4 : Hasil Pengukuran Organoleptik Bau

\begin{tabular}{cccccc} 
& & \multicolumn{4}{c}{ Bau } \\
\cline { 3 - 6 } No. & Unit & \multicolumn{2}{c}{ Sebelum } & \multicolumn{2}{c}{ Sesudah } \\
\cline { 3 - 6 } & & Percobaan & \multicolumn{2}{c}{ Tidak } \\
& & \multicolumn{2}{c}{ Berbau $\begin{array}{c}\text { Tidak } \\
\text { berbau }\end{array}$} & \\
1. & Serbaupel 1.1 & $\checkmark$ & - & $\checkmark$ & - \\
2. & Sampel 1.2 & $\checkmark$ & - & $\checkmark$ & - \\
3. & Sampel 1.3 & $\checkmark$ & - & $\checkmark$ & - \\
4. & Sampel 2.1 & $\checkmark$ & - & $\checkmark$ & - \\
5. & Sampel 2.2 & $\checkmark$ & - & $\checkmark$ & - \\
6. & Sampel 2.3 & $\checkmark$ & - & $\checkmark$ & - \\
7. & Sampel 3.1 & $\checkmark$ & - & $\checkmark$ & - \\
8. & Sampel 3.2 & $\checkmark$ & - & $\checkmark$ & - \\
9. & Sampel 3.3 & $\checkmark$ & - & $\checkmark$ & - \\
\hline & Bau tanpa & $\checkmark$ & - & $\checkmark$ & - \\
\hline
\end{tabular}

Pengukuran organoleptik bau pada air yang mengandung besi $(\mathrm{Fe})$ dilakukan sebelum perlakuan dan sesudah perlakuan dengan menggunakan arang sekam padi. Pengukuran organoleptik bau menggunakan 5 orang pane-lis, yang masing-masing panelis membau air yang mengandung besi $(\mathrm{Fe})$ tersebut. Peng-ukuran organoleptik bau pada air yang meng-andung besi (Fe) pada tabel 3.4. Pemeriksaan organoleptik bau diperiksa oleh 5 orang pa-nelis, yang masing-masing panelis membau air yang mengandung besi $(\mathrm{Fe})$ tersebut. Pada sampel sebelum perlakuan terdapat 1 orang panelis menyatakan bahwa air besi $(\mathrm{Fe})$ tersebut tidak berbau, tetapi 4 orang panelis lainya menyebutkan bahwa air besi yang mengandung besi $(\mathrm{Fe})$ tersebut berbau besi dan pada sampel setelah perlakuan seluruh panelis menyatakan bahwa air yang mengandung besi $(\mathrm{Fe})$ tersebut berbau besi $(\mathrm{Fe})$, selanjutnya pada sampel yang tanpa perlakuan mendapatkan hasil bahwa air yang mengandung besi $(\mathrm{Fe})$ tersebut juga berbau besi $(\mathrm{Fe})$.

Bau pada air dapat disebabkan oleh polutan logam, namun dapat pula disebabkan oleh Hidrogen Sulfda $\left(\mathrm{H}_{2} \mathrm{~S}\right)$, bahan organik (dissolved organic carbon), alga dan bakteri (Tika Arifani dan Ririh 2013). Pada peneletian ini air yang mengandung besi $(\mathrm{Fe})$ berbau besi. Namun bau besi kemungkinan dapat disebab-kan oleh bahan terlarut yang digunakan untuk membuat air tersebut mengandung besi $(\mathrm{Fe})$ yaitu, $\mathrm{FeCl}_{2}$. e. Kekeruhan

Tabel 3.5 : Hasil Pengukuran Kekeruhan

\begin{tabular}{clcc}
\hline & & \multicolumn{2}{c}{ Kekeruhan (NTU) } \\
\cline { 3 - 4 } No. & Unit Percobaan & $\begin{array}{c}\text { Sebelum } \\
\text { Perlakuan }\end{array}$ & $\begin{array}{c}\text { Sesudah } \\
\text { Perlakuan }\end{array}$ \\
\hline 1. & Sampel 1.1 & 14 & 20 \\
2. & Sampel 1.2 & 14 & 30 \\
3. & Sampel 1.3 & 14 & 50 \\
4. & Sampel 2.1 & 14 & 50 \\
5. & Sampel 2.2 & 14 & 50 \\
6. & Sampel 2.3 & 14 & 50 \\
7. & Sampel 3.1 & 14 & 80 \\
8. & Sampel 3.2 & 14 & 80 \\
9. & Sampel 3.3 & 14 & 80 \\
\hline \multicolumn{6}{r}{} & Minimal & 14 & 20 \\
\hline & Maksimal & 14 & 80 \\
\hline & Rata-rata & 14 & 54,4 \\
\hline & Kekeruhan & \multicolumn{2}{c}{14 NTU } \\
\hline
\end{tabular}

Pengukuran kekeruhan pada air yang mengandung besi $(\mathrm{Fe})$ dilakukan sebelum perlakuan dan sesudah perlakuan dengan menggunakan arang sekam padi. Pengukuran kekeruhan menggunakan Turbidity Meter yang memiliki satuan NTU. Data hasil pengukuran kekeruhan air yang mengandung besi $(\mathrm{Fe})$ se-belum perlakuan dan sesudah perlakuan menggunakan arang sekam padi dapat dilihat pada tabel 3.5. Hasil kekeruhan minimum sebelum perlakuan : 14 NTU dan kekeruhan sesudah perlakuan : 20 NTU, selanjutnya keke-ruhan maksimum sebelum perlakuan : 14 NTU dan kekeruhan setelah perlakuan : $80 \mathrm{NTU}$, sedangkan rata-rata kekeruhan sebelum perla-kuan : 14 NTU dan sesudah per-lakuan : 54,4 NTU, selanjutnya pada sampel tanpa perlakuan kekeruhan yang didapat yaitu 14 NTU. Terdapat kenaikan kekeruhan setelah perla-kuan.

Hasil pemeriksaan kekeruhan pada saat penelitian : $20-80$ NTU. Hasil tersebut tidak memenuhi syarat sesuai dengan Permenkes No. 32 Tahun 2017 tentang Standar Baku Mutu Kesehatan Lingkungan dan Persyaratan Kesehatan Air untuk Keperluar Higiene Sanitasi, Kolam Berenang, Solusi Per Aqua dan Pemandian Umum yang disebutkan bahwa untuk higiene sanitasi standar kekeruhan yaitu 25 NTU. Pada penelitian ini kemungkinan yang menyebabkan hasil kekeruhan tidak memenuhi syarat yaitu kurang maksimalnya pada proses filtrasi yang disebabkan oleh partikel pasir yang terlalu besar sehingga partikel-partikel halus yang tersuspensi dalam air tidak dapat tersaring. Bak filter yang menggunakan media pasir dengan ukuran butiran yang sangat kecil, tetapi mempunyai kuarsa yang tinggi (SNI 3981 2008). Dengan demikian semakin kecil ukuran partikel dalam filter, maka semakin banyak suspensi yang tersaring. 
Filtrasi merupakan proses pemisahan solid-solid dengan cara melewatkan liquid melalui maedia berpori atau bahan-bahan berpori untuk menyisihkan atau menghilangkan sebanyak-banyaknya butiran - butiran halus zat padat tersuspensi dari liquida (Sri Widiyastuti dan Antik, 2011).

Menurut Griswidia, 2008 (dalam Hari Sudarmono 2010), faktor yang mempengaruhi efiensi penyaringan terdapat 4 faktor, yaitu :

a.

Semakin tebal media lapisan filter, maka luas permukaan penahan partikel-partikel semakin besar dan jarak yang ditempuh oleh air semakin panjang. Hal ini akan memperpanjang kesempatan media filter untuk memfilter, sedangkan untuk mendapatkan air bersih diperlukan ketebalan minimal $70 \mathrm{~cm}$.

b.

$$
\text { Pengaruh Temperatur Air terhadap }
$$$$
\text { Temperatur Air }
$$

\section{Ketebalan}

Jika temperatur air semakin tinggi, maka kekentalan air akan semakin rendah, sehingga gaya gesek air akan lebih cepat melalui celah tersebut dengan demikian akan memperndek waktur filtrasi.

Pengaruh terhadap Aktivasi Biologi

Temperatur air dapat mempengaruhi kecepatan metabolisme bakteri dalam air, apabila temperatur mencapai optimum untuk perkembangbiakan bakte-ri, maka bakteri akan bertambah dengan cepat.

Pengaruh Temperatur terhadap Reaksi Kimia

Apabila temperatur semakin tinggi, maka reaksi kimia akan semakin cepat, sebaliknya apabila temperatur semakin rendah maka reaksi kimia akan semak-in lambat. Temperatur akan mepenga-ruhi kecepatan reaksi-reaksi kimia.

\section{c. Kecepatan filtrasi}

Kecepatan aliran akan mempengaruhi proses penahanan mekanis terhadap bahanbahan tersuspensi. Apabila kecepatan filtrasi meningkat, efektivitas filtrasi akan menurun.

d.

Semakin rendah kualitas air yang akan difilter, maka akan semakin memerlukan pengolahan yang sempurna atau kompleks.

Berdasarkan hal tersebut pada yang tidak terkontrol oleh peneliti yaitu ketebalan lapisan media filter yang tidak diperhatikan. Menurut Griswedia, 2008 (dalam Hari Sudar-mono 2010), bahwa ketebalan pasir $70 \mathrm{~cm}$ yang paling efektif yang menyaring suspensi dalam air,sedangkan pada penelitian yang dila-kukan ketebalan pasir hanya $5 \mathrm{~cm}$, sehingga dapat dipastikan bahwa kandungan tersuspensi pada air tidak tersaring dengan baik.

Kecepatan air juga mempengaruhi hasil dari filtrasi, semakin cepat aliran pada filtrasi maka keefektivan filtrasi akan menurun (Griswedia, 2008 dalam Hari Sudarmono 2010). Pada saat penelitian peneliti tidak memperhati-kan kecepatan aliran filtrasi, sehingga memungkinkan hasil filtrasi yang dilakukan tidak maksimal. Atas dasar tersebut, maka pada saat melakukan filtrasi untuk lebih memperhatikan tebal media dan kecepatan alira airnya, agar mendapatkan hasil yang baik.

Kekeruhan sangat berpengaruh dalam pemeriksaan kadar besi $(\mathrm{Fe})$ padi air jika menggunakan alat spektrofotometer yang menggunakan prinsip panjang gelombang. Prinsip kinerja spektrofotmeter bila cahaya (monokrommatik maupun campuran jatuh pada suatu medium homogen, sebagian dari sinar masuk akan dipantulkan sebagian diserap dalam medium itu dan sisanya diteruskan. Nilai yang keluar dari cahaya yang diteruskan dinyatakan dalam nilai adsorbansi karena memiliki hubungan dengan konsentrasi sampel (Elliwati $\mathrm{H}$, 2015). Berdasarkan hal tersebut kekeruhan sangat berpengaruh terhadap pemeriksaan kadar besi $(\mathrm{Fe})$ pada air jika menggunakan alat spektrofotometer, dikarenakan partikel-partikel yang tersuspensi tersebut menutupi sinar yang keluar, sehingga menghasilkan nilai yang rendah.

\section{f. Besi}

\section{Tabel 3.6 Hasil Pengukuran Kadar Besi}

\begin{tabular}{|c|c|c|c|}
\hline \multirow[b]{2}{*}{ No. } & \multirow{2}{*}{$\begin{array}{c}\text { Unit } \\
\text { Percobaan }\end{array}$} & \multicolumn{2}{|c|}{ Kadar Besi $(\mathrm{Fe}) \mathrm{Mg} / \mathrm{l}$} \\
\hline & & $\begin{array}{c}\text { Sebelum } \\
\text { Perlakuan }\end{array}$ & $\begin{array}{c}\text { Sesudah } \\
\text { Perlakuan }\end{array}$ \\
\hline 1. & Sampel 1.1 & 2,88 & 5,15 \\
\hline 2. & Sampel 1.2 & 2,88 & 11,74 \\
\hline 3. & Sampel 1.3 & 2,88 & 5,41 \\
\hline 4. & Sampel 2.1 & 2,88 & 4,78 \\
\hline 5. & Sampel 2.2 & 2,88 & 4,79 \\
\hline 6. & Sampel 2.3 & 2,88 & 4,96 \\
\hline 7. & Sampel 3.1 & 2,88 & 5,90 \\
\hline 8. & Sampel 3.2 & 2,88 & 12,42 \\
\hline 9. & Sampel 3.3 & 2,88 & 25,40 \\
\hline & Minimal & 2,88 & 4,78 \\
\hline & Maksimal & 2,88 & 25,40 \\
\hline & Rata-rata & 2,88 & 12,30 \\
\hline & $\begin{array}{l}\text { Kadar besi } \\
\text { (Fe) tanpa } \\
\text { perlakuan }\end{array}$ & \multicolumn{2}{|c|}{$14 \mathrm{NTU}$} \\
\hline
\end{tabular}

Pengukuran kadar besi $(\mathrm{Fe})$ pada air yang mengandung besi $(\mathrm{Fe})$ dilakukan sebelum perlakuan dan sesudah perlakuan dengan menggunakan arang sekam padi. Pengukuran kadar besi menggunakan spektofotometer. Data hasil pengukuran kadar besi $(\mathrm{Fe})$ pada air yang 
mengandung besi $(\mathrm{Fe})$ sebelum perlakuan dan sesudah perlakuan dapat dilihat pada tabel. 3.6.

Pada perlakuan dengan menggunakan a-rang sekam padi $1 \mathrm{~kg}$ mendapatkan hasil rata-rata 7,47 $\mathrm{mg} /$ 1. Pada perlakuan dengan meng-gunakan arang sekam padi $2 \mathrm{~kg}$ mendapatkan hasil ratarata $4,84 \mathrm{mg} / \mathrm{1}$. Pada perlakuan dengan menggunakan arang sekam padi $3 \mathrm{~kg}$ mendapatkan hasil 14,57 mg/ 1 .

Kadar besi $(\mathrm{Fe})$ dalam air setelah diberi perlakuan mengalami peningkatan, terdapat beberapa faktor penunjang yang menyebabkan kadar besi $(\mathrm{Fe})$ tersebut mengalami peningka-tan, seperti tidak adanya perlakuan khusus pada arang sekam padi yaitu pencucian arang sekam padi. Seperti pada penelitian yang dilakukan oleh Nurhasni, dkk., (2014) yang melakukan pencucian pada arang sekam padi yang bertujuan untuk mengilangkan kotoran-kotoran yang menempel pada arang sekam padi ter-sebut. Berdasarkan hal tersebut sebelum mela-kukan penelitian maka harus dilakukan pen-cucian pada arang sekam padi.

g. Prosentase Pengukuran Kadar Besi

Tabel 3.7 : Hasil Prosentasi Pengukuran Kadar Besi

\begin{tabular}{ccccc}
\hline No & $\begin{array}{c}\text { Unit } \\
\text { Percobaan }\end{array}$ & Pre & Post & $\begin{array}{c}\text { Prosesntase } \\
\text { Penurunan(\%) }\end{array}$ \\
\hline 1 & Sampel 1.1 & 2,88 & 5,15 & $-78,81$ \\
2 & Sampel 1.2 & 2,88 & 11,74 & $-307,63$ \\
3 & Sampel 1.3 & 2,88 & 5,41 & $-87,84$ \\
4 & Sampel 2.1 & 2,88 & 4,78 & $-65,97$ \\
5 & Sampel 2.2 & 2,88 & 4,79 & $-66,31$ \\
6 & Sampel 2.3 & 2,88 & 4,96 & $-72,22$ \\
7 & Sampel 3.1 & 2,88 & 5,90 & $-104,86$ \\
8 & Sampel 3.2 & 2,88 & 12,42 & $-331,25$ \\
9 & Sampel 3.3 & 2,88 & 25,40 & $-781,94$ \\
\hline \multicolumn{6}{c}{ Minimum } & $-65,97$ \\
\hline \multicolumn{6}{c}{ Maksimum } & $-781,94$ \\
\hline \multicolumn{6}{c}{ Rata-rata } & $-210,75$ \\
\hline
\end{tabular}

Kadar besi pada masing-masing perlakuan dalam hitungan prosentasi berdasarkan tabel 3.7 pada prosentase penurunan kadar besi (Fe) pada air masing-masing perlakuan antara $65,97 \%$ sampai $-781,94 \%$. Tanda positif menandakan terjadi penurunan kadar besi (Fe) setelah perlakuan dengan menggunakan arang sekam padi dan tanda negatif menandakan terjadi peningkatan kadar besi (Fe) setelah perlakuan dengan menggunakan arang sekam padi.

Peningkatan kadar besi (Fe) terjadi akibat tidak adanya perlakuan khusus pada arang sekam padi tersebut, seperti pencucian arang sekam padi, serta kualitas dari arang sekam padi itu sendiri.Peneliti menduga penye-bab terjadinya peningkatan kadar besi (Fe) pada air tersebut berasal dari arang sekam padi yang sudah mengandung besi mikro. Besi mikro pada arang sekam padi dapat berasal dari berbagai faktor. Pada saat pembakaran terdapat besi-besi mikro pada lingkungan sekitar pem-bakaran yang tercampur pada arang sekam padi. Media atau alat yang digunakan untuk membakar arang sekam padi seperti oven yang sudah berkarat, alat penganduk seperti skop yang berkarat,selain itu besi mikro juga dapat berasal dari proses fisika maupun mekanik pada besi itu tersenditi.Besi mikro dapat ter-larut pada $\mathrm{pH}$ yang rendah $<7$ (Endang dan Hadi, 2015). Hal tersebut terbukti pada tabel 3.2, dengan $\mathrm{pH}$ yang rendah kadar besi meningkar. Berdasarkan hal tersebut, maka perlu diperhatikan kembali pada saat melakukan penelitian menggunakan arang se-kam padi.

Sekam padi menjadi salah alternatif bahan baku adsorben yang potensial. Beberapa keunggulan yang dimiliki oleh sekam padi sebagai kandidat adsorben diantaranya adalah tidak larut dalam air, memiliki stabilitas kimia yang baik dan kekuatan struktur yang baik karena memiliki kandungan Silika yang tinggi. (Vika, 2018).

Berbagai keunggulan yang dimiliki oleh arang sekam padi yang seharusnya dapat menjadi media adsorben yang baik, tetapi dika-renakan kualitas arang sekam padi yang tidak diketahui oleh peneliti menyebabkan arang sekam padi tersebut meningkatkan kandungan besi pada air. Dengan demikian hal tersebut perlu diperhatikan kembali pada penelitian lebih lanjut.

\section{Bivariate}

Pengaruh Pemakaian Arang Sekam Padi terhadap Penurunan Kadar Besi (Fe)

Tabel 3.8Pengaruh Pemakaian Arang Sekam

Padi terhadap Penurunan Kadar Besi (Fe)

\begin{tabular}{lccc}
\hline \multicolumn{4}{c}{ Test Statistics $^{\mathbf{b}}$} \\
\hline & Hasil & Hasil & Hasil \\
& Pre -Post & Pre -Post & Pre - Post \\
& $\begin{array}{c}\text { Perlakuan 1 } \\
\text { kg }\end{array}$ & $\begin{array}{c}\text { Perlakuan 2 } \\
\text { kg }\end{array}$ & $\begin{array}{c}\text { Perlakuan3 } \\
\text { kg }\end{array}$ \\
\hline $\mathrm{Z}$ & $-1.604^{\mathrm{a}}$ & $-1.604^{\mathrm{a}}$ & $-1.604^{\mathrm{a}}$ \\
\hline $\begin{array}{l}\text { Asymp. } \\
\text { Sig. (2- } \\
\text { tailed) }\end{array}$ & & & \\
\hline
\end{tabular}

Penelitian yang dilakukan untuk mengetahui pengaruh pemakaian arang sekam padi dianalisis menggunakan Wilcoxon. Berdasar-kan pada tabel 3.8 nilai $\mathrm{Z}$ yang bertanda negatif tidak memiliki arti terdapat peningkatan atau penurunan pada kadar besi setelah penggunaan arang sekam padi dikarenakan data yang di-dapat tidak terdistribusi normal, sedangakan untuk nilai siginifikasi, ketiga perlakuan mem-punyai nilai signifikasi > 0,05 yaitu 0,109 yang berarti tidak ada perbedaan kadar besi (Fe) sebelum dan sesudah diberi perlakuan dengan menggunakan 
arang sekam padi. Variasi berat arang $1 \mathrm{~kg}, 2 \mathrm{~kg}$ dan $3 \mathrm{~kg}$ memiliki nilai sig-nifikasi sama dikarenakan dianalisis menggu-nakan Wilcoxon yang model penilaian siginifi-kasinya berdasarkan ranking.

\section{Multivariate}

Pengaruh Perbedaan Penurunan Kadar Besi (Fe) dengan Variasi berat Arang Sekam Padi

Tabel 3.9 : Hasil Uji Homgenitas

\begin{tabular}{lr}
\multicolumn{2}{c}{ Test Statistics $^{\mathbf{a}, \mathbf{b}}$} \\
\hline \multicolumn{2}{c}{ Hasil Pengukuran Fe } \\
\hline Chi-Square & 6,489 \\
Df & 2 \\
Asymp. Sig. &, 039 \\
\hline
\end{tabular}

Penelitian yang dilakukan untuk mengetahui pengaruh perbedaan penurunan kadar besi $(\mathrm{Fe})$ dengan variasi berat arang sekam padi dianalisis menggunakan uji Kruskal Wallis, berdasarkan tabel 3.9 menunjukkan hasil yang signifikan $<0,05$ yaitu 0,039 yang berarti terdapat pengaruh penggunaan varias berat arang sekam padi terhadap kadar besi ( $\mathrm{Fe}$ ) pada air. Setelah mengatahui hasil tersebut sig-nifikan maka dilanjut ke uji U Mann Withney yang bertujuan untuk mengetahui variasi berat arang sekam padi manakah yang berpengaruh pada kadar besi (Fe) pada air.

Tabel 3.10Hasil Uji Statistik UMann Withney Pengaruh Penggunaan Arang Sekam Padi dengan Variasi berat $1 \mathrm{~kg}$ dan $2 \mathrm{~kg}$ terhadap Penurunan Kadar Besi (Fe)

\begin{tabular}{lr}
\multicolumn{2}{c}{ Test Statistics $^{\text {a }}$} \\
\hline & Hasil pemeriksaan \\
\hline Mann-Whitney U &, 000 \\
Wilcoxon W & 6,000 \\
Z & $-1,964$ \\
Asymp. Sig. (2-tailed) &, 050 \\
Exact Sig. [2*(1-tailed &, $100^{\mathrm{b}}$ \\
Sig.)] & \\
\hline
\end{tabular}

Berdasarkan tabel 3.10 pada variasi berat arang sekam padi dengan berat $1 \mathrm{~kg}$ dan $2 \mathrm{~kg}$ menunjukkan hasil siginifikan 0,05, sehingga nilai siginifikan $<0,05$ atau sama dengan 0,05 yang berarti pada salah satu berat arang sekam padi tersebut ada yang berpengaruh dalam penurunan kadar besi $(\mathrm{Fe})$ pada air.

Tabel 3.11 Hasil Uji StatistikU Mann WithneyPengaruh Penggunaan Arang Sekam Padi dengan Variasi Berat $1 \mathrm{~kg}$ dan 2 kg terhadap Penurunan Kadar Besi (Fe)

\begin{tabular}{|c|c|}
\hline \multicolumn{2}{|c|}{ Test Statistics ${ }^{\mathbf{a}}$} \\
\hline Hasil & \\
\hline Mann-Whitney U & 1,000 \\
\hline Wilcoxon W & 7,000 \\
\hline $\mathrm{Z}$ & $-1,528$ \\
\hline Asymp. Sig. (2-tailed) & 127 \\
\hline Exact Sig. [2*(1-tailed Sig.)] & $200^{\mathrm{b}}$ \\
\hline
\end{tabular}

Berdasarkantabel 3.11 yaitu variasi berat arang sekam padi dengan berat $1 \mathrm{~kg}$ dengan $3 \mathrm{~kg}$ menunjukkan hasil siginifikan $>0,05$ yaitu 0,127 yang berarti diantara berat arang sekam padi $1 \mathrm{~kg}$ dan $3 \mathrm{~kg}$ tidak ada pengaruh dalam penurunan kadar besi (Fe) pada air.

Tabel 3.12 Hasil Uji StatistikU Mann WithneyPengaruh Penggunaan Arang Sekam Padi dengan Variasi Berat 2 kg dan $3 \mathrm{~kg}$ terhadap Penurunan Kadar Besi (Fe)

\begin{tabular}{lr}
\hline \multicolumn{2}{c}{ Test Statistics $^{\mathrm{a}}$} \\
\hline \multicolumn{2}{c}{ Hasil pemeriksaan } \\
\hline Mann-Whitney U & 1,000 \\
Wilcoxon W & 7,000 \\
$\mathrm{Z}$ & $-1,528$ \\
Asymp. Sig. (2-tailed) &, 127 \\
Exact Sig. [2*(1-tailed Sig.)] &, $200^{\mathrm{b}}$ \\
\hline
\end{tabular}

Berdasarkan tabel 3.12 variasi berat arang sekam padi dengan berat $2 \mathrm{~kg}$ dan $3 \mathrm{~kg}$ menunjukkan hasil signifikan yaitu 0,05 , sehingga nilai signifikannya $<0,05$ atau sama dengan 0,05 yang berarti salah satu dari variasi berat arang sekam padi berpengaruh dalam penurunan kadar besi (Fe) pada air.

Hasil dari analisis U Mann Withney menunjukkan bahwa variasi berat arang sekam padi $2 \mathrm{~kg}$ yang paling berpengaruh dalam menurunkan kadar besi (Fe) pada air. Akan tetapi pada kenyataannya dengan variasi berat arang sekam padi yang digunakan tidak ada yang berpengaruh terhadap penurunan kadar besi $(\mathrm{Fe})$ pada air yang mengadung besi $(\mathrm{Fe})$.

\section{Kesimpulan dan Saran}

a. Kesimpulan

Kadar besi (Fe) pada air sebelum perlaku-an dengan menggunakan arang sekam padi sebagai media adsroben adalah $2,88 \mathrm{mg} /$ 1.Rata-rata kadar besi (Fe) pada air setelah perlakuan dengan menggunakan arang sekam padi sebagai media adsorben dengan variasi berat $1 \mathrm{~kg}$ adalah $7,47 \mathrm{mg} / 1$, variasi berat $2 \mathrm{~kg}$ adalah $4,48 \mathrm{mg} / \mathrm{l}$ dan variasi berat $3 \mathrm{~kg}$ adalah 14,57 mg/l.Hasil pengu-kuran $\mathrm{pH}$, suhu, bau, rasa, kekeruhan se-belum perlakuan dengan menggunakan arang sekam padi sebagai media adsorben, yaitu denganpH 3,7, suhu $26^{\circ} \mathrm{C}$, tidak berbau dan tidak berasa, serta kekeruhan sebesar 14.Rata-rata hasil pengukuran $\mathrm{pH}$, suhu, bau, rasa, kekeruhan sebelum perlakuan dengan menggunakan arang sekam padi sebagai media adsorben, yaitu denganpH 3,2, suhu $28^{\circ} \mathrm{C}$, tidak berbau dan tidak berasa, serta kekeruhan sebesar 12,30 NTU.Nilai siginifikan 0,109 yang berarti tidak ada pengaruh secara sig-nifikan penurunan kadar besi (Fe) pada air dengan menggunakan arang sekam padi sebagai media 
adsorben.Tidak terdapat pengaruh perbedaan penurunan kadar besi pada air.

\section{b. Saran}

Perlu dilakukan penelitian lebih lanjut dengan menggunakan arang sekam padi yang lebih memperhatikan kualitas arang sekam padi dan kandungan besi mikro pada arang sekam padi. Jika menggunakan metode adsrobsi perlu memperhatikan media filtrasi yang digunakan, seperti ketebalan media filtrasi, suhu air, kecepatan filtrasi serta kualitas pada air. Menggunakan metode lain dalam mengukur kadar besi (Fe) selain alat spektrofotometer.

\section{DAFTAR PUSTAKA}

Arief, H, Masyamsi, Dhahiyat Y. 2012. Distribusi Kandungan Logam Berat $\mathrm{Pb}$ dan $\mathrm{Cd}$ Pada Kolom Air dan Sedimen Daerah Aliran Sungai Citarum Hulu. Jurnal Perikanan dan Kelautan Universitas Padjajaran: Bandung. Tersedia di http://jurnal.unpad.ac.id diakses pada 30 April 2019 pukul 14.34.

Distika, Adhi., dkk. 2017. Efektivitas Ampas Teh sebagai Adsorben Alternatif Logam $\mathrm{Fe}$ dan Cu pada Air Sungai Mahakam. Jurnal Teknik Kimia. Samarinda: Universitas Mu-lawarman. Tersedia di https://jurnal.untirta.-ac.id diakses pada 1 Desember 2018 pukul 20.02
Elliwati Hasibuan. 2015. Pengenalan Spektrofotometri pada Mahasiswa yang Melakukan Penelitian di Laboratorium Terpadu Fa-kultas Kedokteran USU. Sumatera Utara : Universitas Sumatera Utara. Tersedia direpository.usu.ac.id diakses pada 25 Mei 2019 pukul 20.02

Endang Supriyantini dan Hadi Endrawati. 2015. Kandungan Logam Berat Besi (Fe) pada Air, Sedimen, Kerang Hijau (Perna viridis) di Perairan Tanjung Mas Semarang. Jurnal Fakultas Perikanan dan Kelautan Univer-sitas Diponegoro : Semarang. Tersedia di https://ejournal2.undip.ac.id diakses pada 1 Mei 2019 pukul 14.50.

Harmin S,T., dan I Made Padang. 2006. Penurunan Warna Limbah Cair Industri Pencelupan Tekstil dengan Menggunakan Adsorben Arang Sekam Padi. Jurnal Teknik Lingkungan. Surabaya: Institut Tinggi 10 Nopember. Tersedia di https://purifikasi.id diakses pada 1 Desember 2018. 